\title{
Similarity and Competition of Polish Agri-food Export with the Largest Agricultural Producers in the EU. Analysis of EU, US and China Market
}

\author{
Bartłomiej Bajan ${ }^{1}$, Joanna Łukasiewicz' ${ }^{1}$ Luboš Smutka ${ }^{2}$ \\ ${ }^{1}$ Faculty of Economics and Social Sciences, Poznan University of Life Sciences, Poland \\ ${ }^{2}$ Faculty of Economics and Management, Czech University of Life Sciences Prague, Czech Republic
}

\begin{abstract}
Poland is one of the largest agricultural producers within European Union (EU). Since joining EU in 2004, Poland has significantly increased its agri-food trade turnover and strengthened its net exporter standing in this regard. With the understanding that countries exporting similar goods to a specific market can be considered competitors, the examination covered similarities in Poland's export of agri-food products compared to the two largest agricultural producers in EU, namely Germany and France, in three markets: EU-28, China and United States. The agri-food export was analyzed in terms of structure, value and quality, using ComExt data. The growth of the Polish agri-food trade following the accession to the European Union, allowed the country to become a competitor to the common market's biggest agricultural producers. Poland's competitiveness in the US market in relation to Germany is also rising. On the other hand, looking at the Chinese market, the value of the exported agri-food products is too low to consider Poland a major competitor to Germany or France. Poland's competitiveness in the trade of agri-food products is relatively well covered in the literature, but the studies usually focus on the issue of volume and structure or comparative advantages. The export similarity is omitted, in particular with regard to Central and Eastern European countries (CEEC) and to quality similarities issues. The study also suggests a way to identify countries similar in terms of export structure that is based on entire population results. This study fills in a certain research gap that emerged in the context of CEEC, consisting in the analysis of Poland's export in the background of EU's largest agricultural producers.
\end{abstract}

\section{Keywords}

Agri-food sector, export, structure similarity, international competitiveness.

Bajan, B., Łukasiewicz, J. and Smutka, L. (2021) "Similarity and Competition of Polish Agri-food Export with the Largest Agricultural Producers in the EU. Analysis of EU, US and China Market", AGRIS on-line Papers in Economics and Informatics, Vol. 13, No. 1, pp. 29-47. ISSN 1804-1930. DOI 10.7160/aol.2021.130103.

\section{Introduction}

As per Eurostat (ComExt) data, on the year of Poland's accession to European Union, the agrifood products accounted for nearly $9 \%$ of the total export, value at around EUR 5.3 billion. Since the accession to EU in 2004, the dynamics of the export of agri-food products from Poland has risen significantly. In 2019, the export of the discussed products was valued at around EUR 31.5 billion, accounting for $13 \%$ of Poland's total export. The agri-food products trade balance also improved, because export has been rising relatively more quickly than import. The trade balance for products of agricultural origin was EUR 0.8 billion in 2004. Growing successively, it reached around EUR 10.4 billion in 2019. Just like pre-accession, EU states have remained Poland's main trade partners. Nearly $75 \%$ of all exported agri-food products reached this market in 2004 , and around $81 \%$ in 2019.

Even before joining EU, CEEC enjoyed close relations with EU states, based on free trade agreements signed in 1995 (Caporale et al., 2012). Despite the growing turnover, trading in some products was still limited due to non-tariff barriers. This problem was ultimately eliminated by joining the European Union, which resulted in opening the market completely (Marques, 2011). A common market exists within EU, within which goods, labor and capital can freely cross the states' borders. 
The member states have lifted duties for each other and, as a part of a customs union, set out a common trade policy (Larue, 2018). Such facilitations intensify trade within the common, but may also impact export orientation towards third countries, if only by growing certain industries, caused by access to a bigger market. Finally, trade changes may lead to increased competition among the member states (Pawlak, 2018; Maciejewski and Wach, 2019). This, in turn, leads to deepening the differences in performance and economic growth tendencies in European countries (Bilan et al., 2020; Blázquez-Fernández et al., 2018).

As indicated by Svatoš et al. (2013), following the accession to EU, Poland's agri-food production and trade turnover of agri-food products increased significantly. This translated into increased comparative advantages in food export, both in relation to EU states and in the global market in general. It can be therefore concluded that the competitiveness of the Polish agri-food trade has risen. Svatoš and Smutka (2012) found that, among others, Poland significantly changed the structure of its agri-food trade in the postaccession period, simultaneously managing to get higher unit prices for its goods. These changes may indicate the growing quality of the exported goods, but also to the significance of changes in export structure from the perspective of the growth of competitiveness (Janda et al., 2013). This conclusion is drawn from the simultaneous improvement of comparative advantages in relation to EU states and the altered export structure, which was also confirmed by Bojnec and Fertö (2009). Indeed, the similarity within the structure of export to a given market may point to the fiercer competition among the studied entities (Abrham et al., 2015; De Benedictis and Tajoli, 2007; Bang and Tuo, 2013; Luo et al., 2018; Maciejewski, 2019; Yang et al., 2019).

In the presented context, the objective of the study was to measure the similarity of Poland's export with regard to agri-food products to the export by Germany and France, the two largest agricultural producers in European Union. The purpose of the study is to show the growth or drop of competitiveness in the export of agrifood products to three markets: EU-28, China and United States. These markets have been selected since they are the largest recipients of EU agri-food products. The similarity of the export structure, the export's value and quality were analyzed in each of these markets. Reference literature provides plenty of research on competitiveness of the Polish, and more broadly, EU agri-food export, but is usually focused on the issues of volume and structure or comparative advantages (Torok and Jambor, 2013; Bojnec and Fertö, 2015), but it fails both to study the very similarity of export to a given market, in particular to CEEC, and the quality aspects. Such studies were conducted, by Antimiani et al. (2012), for a bigger group of states in the view of their accession to EU, but only with regard to the value of export for two periods: pre- and post-accession. Based on this research, Poland's increasing competitiveness on the EU-15 market has been identified. There are also several studies that take into account the quality and structure, but only for EU-15 states. For instance, Antimiani and Henke (2007) found that the export similarity on the EU-15 market is low and when quality is taken into account similarity is even lower. Rondinella et al. (2019) found that agri-food export similarity between Italy and Mediterranean countries is higher in North American market than in EU-28 market in terms of structure and quantity, but not quality. Consequently, this study fills in a certain research gap that emerged in the context of CEEC, consisting in the analysis of Poland's export in the background of EU's largest agricultural producers.

\section{Materials and methods}

The similarity of agri-food export structures among Poland, France and Germany in individual markets were examined on the basis of data from the Eurostat (ComExt) data base. The agri-food products belong to the first 24 chapters classified subject to the Harmonized Commodity Description and Coding System (HS). The similarity indicators were calculated on the basis of data from the level of 8-digit merchandise disaggregation. The export structures of Poland, Germany and France were compared against each other, on three markets: the US, China and UE-28. The study covered the following 2-year periods: 2004/2005, 2009/2010, 2014/2015, 2018/2019. Choosing 2-year periods allows to limit annual fluctuations that may sometimes occur in international trade. Selected time range allows to trace export similarity changes that have occurred since Poland's accession to the EU.

The first examined index is the Export Similarity Index (ESI), originally used by Finger and Kreinin (1979). This is the simplest measure of the similarity of export of two entities into the third market's entity, aiming to compare only the patterns of export for various product categories. Consequently, it is entirely independent from absolute values and only depends 
on the share of individual product categories in total export (Zheng and Qi, 2007). The measure can be represented with a formula:

$E S I_{i j, d}=\sum_{c=1}^{n} \min \left(x_{i, d}^{c}, x_{j, d}^{c}\right)$

where: $x_{i, d}{ }^{c}, x_{j, d}{ }^{c}$ are, respectively, the shares of goods exported (c) from the market (country) $i$ into the target market $(d)$ and from the market (country) $j$ into the target market $(d)$.

The ESI values fluctuate between 0, which represents a complete lack of similarity of the export structure between country $i$ and $j$, into the target market $d$, to 1 , which represents identical structures of export of the analysed countries into the target market. In this study, the shares of individual goods from HS 1-24 are put against the value of the entire agri-food export. 4689 various goods were analysed with regard to 8-digit disaggregation. The level of disaggregation has a major impact on ESI result (Pomfret, 1981). As indicated by Nguyen et al. (2017), ESI values get progressively lower as the level of data disaggregation rises. Antimiani et al. (2012) indicate that reference literature lacks a method of determining which indicator values show a similarity of export structures. Consequently, an arbitrarily determined threshold value is used. Having in mind that the indicator is sensitive to the level of data aggregation, we agreed that the threshold value over which ESI indicates a similarity of structures should be determined on the basis of index results from the entire population (all EU-28 states in this case).

We applied a method of determining the threshold value that is used in the vector elimination algorithm, used for the purpose of determining groups of objects similar in terms of structure (Chomątowski and Sokołowski, 1978). The first step was to create a symmetrical matrix of diversity regarding the export structure of agri-food products [vjp] among UE-28 states, each one against each other. The diversity indicator, which is the result of subtracting the ESI indicator from 1, was calculated for all pairs. A separate matrix was created for each of the three examined markets, in order to determine their applicable threshold values. The $\gamma$ threshold was defined as the difference between the arithmetic mean and standard deviation for non-diagonal entries of the matrix $\left[v_{j p}\right]$ in 2018/2019, as per the following formula (Kukuła, 2010):

$$
\gamma=\bar{v}-S_{v}
$$

with:

$\bar{v}=\frac{2 \sum_{j=1}^{r} \sum_{p>j} v_{j p}}{r(r-1)}$

where: $\bar{v}=$ average value of non-diagonal entries of the structure diversity matrix $\left[v_{j p}\right] ; r=$ number of objects compared (countries)

with:

$S_{v}=\frac{2 \sum_{j=1}^{r} \sum_{j, p}\left|v_{j p}-\bar{v}\right|}{r(r-1)}$

where: $S_{v}=$ mean deviation of non-diagonal entries of the structure diversity matrix $\left[v_{j p}\right]$.

The obtained result was subtracted from 1, so that it can be interpreted as a similarity threshold, rather than a structure diversity threshold. All pairs of countries for which the ESI indicator achieves values that exceed the similarity threshold should be considered similar in terms of the export structure. This method served to determine whether Poland, France and Germany are similar in terms of the examined structure in the analysed markets (ESI results for each pair of EU-28 countries are shown in Appendix. Table A1 shows results on the EU-28 market, Table A2 on the US market, and Table $\mathrm{A} 3$ on the Chinese market). The previously mentioned limitations of the ESI indicator, in particular the omission of absolute export values, were taken into account by calculating the product similarity index (PSI) that shows the degree of overlapping of the absolute values of export streams. The higher the values of this indicator, the higher the similarity of export, and in turn, the higher the competitive pressure between entities in a given market (Rondinella at al., 2019). PSI can be represented with the following formula:

$$
P S I=1-\left[\frac{\sum_{c=1}^{n}\left|X_{i, d}^{c}-X_{j, d}^{c}\right|}{\sum_{c=1}^{n}\left(X_{i, d}^{c}+X_{j, d}^{c}\right)}\right]
$$

where: $X_{i, d}^{c}, X_{j, d}^{c}$ are, respectively, the shares of goods exported (c) from the market (country) $i$ into the target market $(d)$ and from the market (country) $j$ into the target market $(d)$.

Just like with ESI, the value of 0 shows the lack of similarity and 1 indicates that there are identical values of export streams in the given market. The real similarity of export streams may be overstated by the PSI indicator due to failure to take into account the goods quality factor. It is possible that the value of export of a specific product from one country is the same as the one from another country in comparison, but with a markedly different quantity 
of the shipped goods. This may lead to falsification of the real similarity of export into a given market, where entities who are not competitors may be considered to be ones. Aiming to avoid this situation, the quality similarity index (QSI) was also calculated. QSI takes into account only goods from the same category that are similar in terms of quality. QSI may be calculated with a formula (Antimiani and Henke, 2007):

$Q S I=\left\{1-\left[\frac{\sum_{c=1}^{n}\left|X_{i, d}^{c, q}-X_{j, d}^{c, q}\right|}{\sum_{c=1}^{n}\left(X_{i, d}^{c, q}+X_{j, d}^{c, q}\right)}\right]\right\} *\left[\frac{\sum_{c=1}^{n}\left(X_{i, d}^{c, q}+X_{j, d}^{c, q}\right)}{\sum_{c=1}^{n}\left(X_{i, d}^{c}+X_{j, d}^{c}\right)}\right]$

where: $X_{i, d}^{c, q}, X_{j, d}^{c, q}$ are, respectively, the shares of goods exported $(c)$ from the market (country) $i$ into the target market $(d)$ and from the market (country) $j$ into the target market $(d)$. Only goods in the same category and similar in terms of quantity (q) are used in the formula.

The goods quality similarity was determined on the basis of export unit values (XUV). This approach is sometimes met with criticism in reference literature (King, 1993), since unit values are largely dependent on the changes in the quantity of individual goods belonging to the same category. These changes may even take place repeatedly during a year. Relying on XUV as a quality indicator may also be flawed due to the often poor quality of data on the quantity of goods in customs documents (Silver, 2009). Doubts aside, there are no data that may represent the real price in a better way, which would make them a better indicator of quality (Bojnec and Fertö, 2010). Many researchers who use unit values as information about the price invoke Stiglitz's (1987) conclusion that even if the information is imperfect, prices reflect the quality and determine the direction of the trade. For example, Anwar and Sun (2018) empirically confirm in their recent study the validity of using the export unit value as a proxy for export quality. This validity has also been confirmed in other studies using these indicators for measuring the quality in international trade (e.g. Hummels and Klenow, 2005; Mau 2019), or specifically in agri-food trade (e.g. Janský, 2010; Smutka et al., 2019). Hallak (2006) also claims that differences in quality are better seen between less homogeneous goods, whereas goods exhibiting uniform features differ in quality to a lower extent.

This study considers goods that satisfy the condition expressed with the following formula to be of the same quality:
$1-\left(\frac{\left|X U V_{i, d}^{c}-X U V_{j, d}^{c}\right|}{X U V_{i, d}^{c}+X U V_{j, d}^{c}}\right) \geq 0.9$

where: $X U V_{i, d}{ }^{c}, X U V_{j, d}{ }^{c}$ are, respectively, the export unit value of goods $(c)$ from the market (country) $i$ into the target market $(d)$ and from the market (country) $j$ into the target market $(d)$.

The examination of differences in the unit value at a high level of disaggregation should indicate goods that are similar in terms of quality. Additionally, a certain level of permissible error was assumed so as not to exclude goods similar in terms of quality from the QSI analysis. The applied inequality is, in a way, an improvement in relation to the inequality used in other studies (Antimiani and Henke, 2007):

$(1-\alpha)<\left(\frac{X U V_{i, d}^{c}}{X U V_{j, d}^{c}}\right)<(1+\alpha)$

This inequality assumes that the quotient of $X U V_{i}$ and $X U V_{j}$ falls into a certain confidence interval determined by coefficient $\alpha$, set at a range from 0.15 to 0.25 .

However, this measure fails to satisfy the principle according to which the comparison of object A with object $B$ should produce the same result as the comparison of object B with object $A$. In other words, $X U V_{i} / X U V_{j}$ is not equal to $X U V_{j} / X U V_{i}$. It is worth noting that although the differences are usually low at a high level of disaggregation, the measure proposed in our study is free from such error whatsoever. Setting the indicator's value at or above 0.9 is equivalent with the value $\alpha$ in the range between 0.15 and 0.25 .

In the presented form, QSI may assume values between 0 and 1 , where 0 means a complete lack of similarity between the entities with regard to the quality of goods exported to a given market and where 1 means full similarity. In practice, the maximal value of QSI is limited with the value of PSI in that if QSI reaches the value of PSI, then all overlapping streams of exported goods are similar quality-wise, meaning that exporters most certainly compete with each other, because their products have similar utility. As a result, QSI values should be also considered in relation to what part of PSI they constitute.

\section{Agri-food export to the studied markets}

\section{EU-28 market}

EU states are the major trade partners for Poland, Germany and France alike. The value of intra-EU 
trade grew noticeably in 2004-2019 (Figure 1). During the examined period and among the examined countries, the highest values of export to the member states were achieved by Germany, followed by France and Poland.

For all examined periods, meat and edible offal (HS-2) and dairy products (HS-4) accounted for the largest share in the Polish export to the EU market (EU-28). The shares were calculated based on ComExt data. The share of meat and edible offal in the total export of agri-food products was increasing. In 2004/2005 the share accounted for around $15 \%$, while in $2018 / 2019$ for over $17 \%$, which gave a value of almost 9 billion euros. Dairy products accounted for around $12 \%$ of the exported agri-food products in $2004 / 2005$, but this share was diminishing and was around $8 \%$ in 2018/2019. With regard to the export of agri-food products there was a substantial rise in the share of tobacco and manufactured tobacco substitutes (HS-24), from nearly $2 \%$ in $2004 / 2005$ to $13 \%$ in $2018 / 2019$. Additionally, preparations of cereals, flour, starch or milk (HS-19) achieved a relatively high share in the export (6-7\%) during all examined periods.

Similarly as with Poland, the largest share in the agri-food export from Germany was achieved by meat and edible offal and dairy products. The share of dairy products in the total export was diminishing. In 2004/2005 these products accounted for $16 \%$ of the agri-food export, and in 2018/2019 - 13\%, which gave a value of 15 billion euros. For meat and edible offal, in 2004/2005 their share in the agri-food export was $11 \%$, and $13 \%$ in $2009 / 2010$, subsequently dropping to $11 \%$ in $2014 / 2015$ and to $10 \%$ in $2018 / 2019$. A relatively high share of preparations of cereals, flour, starch or milk can be spotted during the examined periods when analyzing the structure of export. These products made up 8-9\% of agri-food export to the EU-28 market.

Unlike in Poland and Germany, beverages, spirits and vinegar (HS-22) accounted for the largest share of agri-food export from France into the EU-28 market. These products reached over $17 \%$ of the total export during each of the examined periods. The value of beverages, spirits and vinegar was over 53 billion euros in 2018/2019. Dairy products also had a relatively high share in the export of agri-food products. The value of sales of dairy products in the UE-28 market remained at a similar level, of around 11-12\% of the total export, during all examined periods. A relatively high share of cereals (HS-10) was noted in 2004-2019 in the export of agri-food products to the UE-28 market. Cereals accounted for around $10 \%$ of the exported goods for all examined periods.

\section{US market}

When analyzing the export of agri-food products to the US and Chinese markets, one has to account for the existing trade agreements that constitute of the key elements of EU's trade policy. Such agreements may focus on limiting or eliminating tariff barriers or creating a customs union, thanks to the removal of customs duties and setting out common customs rates for foreign importers (Preeg, 1998). European Union was often approached as a strong player on the international market, because the size of the uniform European market and the organisational and legal structure allowed the EU to strengthen its position in international trade negotiations (Meunier, 2005; Meunier and Nicolaïdis, 2006).

The cooperation between EU and USA has been

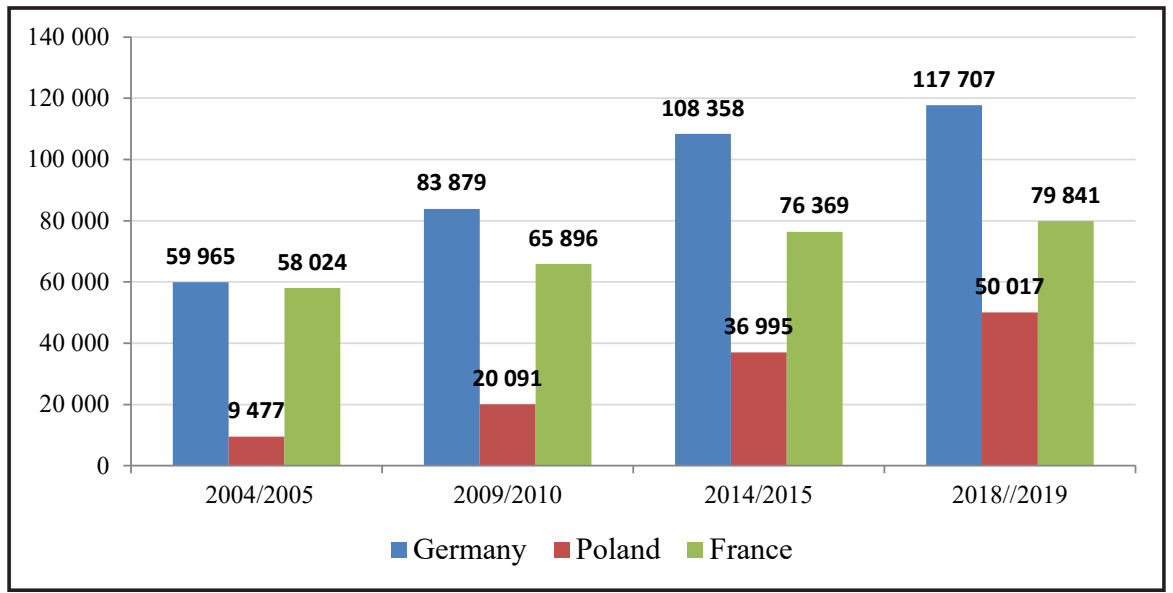

Source: Own elaboration on ComExt data

Figure 1: Agri-food exports to EU-28 (in million euros). 
growing closer and closer for many years. It is here worth mentioning the EU-US Declaration Initiative to Enhance Transatlantic Economic Integration and Growth of 2005, in which the European Union and the United States vowed to seek ways for strengthening transatlantic economic integration and to realize the competitive potential of their economies. Another important element in reinforcing the transatlantic relations was the creation, in 2007, of the Transatlantic Economic Council, a platform for holding negotiations between the EU and the US, aiming at a deeper integration of their economies (Tocci, 2008). In 2013, the US and the EU commenced negotiations on a new trade agreement - the Transatlantic Trade and Investment Partnership, an attempt to reinforce the existing alliances (Novotná et al., 2015).

The value of agri-food export from Poland, Germany and France to the American market was constantly rising in 2004-2019 (Figure 2). According to ComExt data, the value of export from Germany and France increased over two times. The value of the Polish agri-food export to United States increased by over three times.

In 2004/2005 and in 2009/2010, beverages, spirits and vinegar had the biggest share in the export of agri-food products from Poland, reaching almost $25 \%$, along with meat, fish or crustaceans, molluscs or other aquatic invertebrates; preparations there of (HS-16), which accounted for 24\% of agri-food export. In the subsequent period their share dropped to around $20 \%$, but the export of fish and crustaceans, molluscs or other aquatic invertebrates (HS-3) increased rapidly, to over $16 \%$ of the total export. In the following years, namely 2014/2015 and 2018/2019, the share of meat, fish or crustaceans, molluscs or other aquatic invertebrates; preparations thereof in the export of agri-food products was decreasing, down to $12.5 \%$ in $2018 / 2019$. There was a visible increase in the export of meat and edible offal, constituting around $18 \%$ in $2014 / 2015$ and nearly $24 \%$ in $2018 / 2019$, which gave value of over 251 million euros.

During all examined periods, the biggest share in the agri-food export from Germany to the US market belonged to beverages, spirits and vinegar and to coffee, tea, mate and spices (HS-9). However, their share in the total export was decreasing, to reach $15 \%$ for beverages, spirits and vinegar in 2018/2019 and $17 \%$ for coffee, tea, mate and spices, whereas it was, respectively, $37 \%$ and $18 \%$ in $2004 / 2005$. A significant rise in the export of products of the milling industry (HS-11) Their share in the total export was constantly growing during all examined periods. In $2004 / 2015$ the share accounted for nearly $3 \%$, while in $2018 / 2019$ for $9 \%$.

Just like with Germany, the main products sold by France to US were beverages, spirits and vinegar. These accounted for almost $80 \%$ of all agri-food exports in all examined periods, and the value of their exports was over 7 billion euros in $2018 / 2019$. Dairy products had a relatively high share in the French export of agri-food products in 2004-2019. Their share in the total export fluctuated between $4 \%$ and $6 \%$. The remaining groups of products exported from France had a relatively low share in the total export of agri-food products, around 1-2\%.

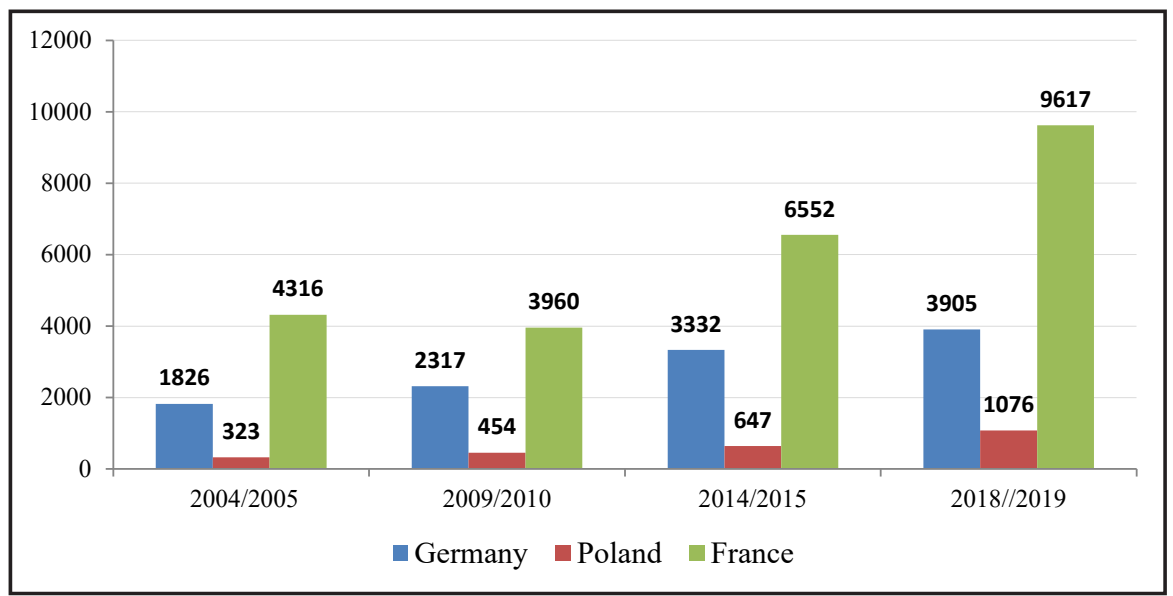

Source: Own elaboration on ComExt data

Figure 2: Agri-food exports to the United States (in million euros). 


\section{Chinese market}

The accession of China to the World Trade Organization (WTO) in 2001 had a large impact on the condition of agri-food trade relations between the EU and China. Following the accession to WTO, China increased import allowances for agri-food products in 2001-2004 (Antimiani and Henke, 2007; Niemi and Huan-Niemi, 2007). The official strategic partnership between China and the EU was initiated in 2003 and prompted the intensification of trade. In 2015, the UE elected to enhance cooperation with China (Brugier, 2017). The solidified economic relations lead to a substantial increase in trade, which eventually made China the EU's second biggest trade partner, following the US (Fang and Skahur, 2018). The resolution of the European Parliament, dated September 12, 2018, on the relations between the European Union and China underscores that China is the fastest growing market for food products from the EU.

In 2004-2019, Poland, Germany and France increased their export of agri-food products to the Chinese market (Figure 3). Poland's export volume was the lowest, with Germany and France achieving markedly higher numbers, which, after 2010, became more similar to each other.

The Chinese market mainly received dairy products from Poland. Starting from 2004, their share grew from period to period, to reach nearly $40 \%$ of the agri-food exports in 2018/2019, which was around 130 million euros. A large share of products of animal origin (HS-5) in the export was also reported in 2004/2005 and 2009/2010. These products accounted for around $40 \%$ of all agri-food products sold, however, their share dropped rapidly to below $3 \%$ in $2014 / 2015$. During this period, the export of meat and edible offal saw another rise. These products accounted for $20 \%$ of the total export in $2004 / 2005$, but this volume dropped to less than $2 \%$ in the subsequent period. In 2014/2015 and 2018/2019 the sales of meat and edible offal grew again, resulting in achieving a share of around $17 \%$ of the exported agri-food products. Such far-reaching changes in the export of agricultural origin products may be affected by quality standards of certain groups of products, the global financial crisis of 2008 and import limitations introduced by China (see e.g. Guo et al., 2011; Priede and Feng, 2017; Taylor and Jaussaud, 2018).

Similarly to Poland, the largest share in the export from Germany in 2004/2005 belonged to products of animal origin (around 24\%), whereas in other periods these were dairy products, which constituted around $20 \%$ of the exported agri-food products in 2009/2010 and 2014/2015 and around $15 \%$ in 2018/2019. 2009/2010 and 2014/2015 saw the rise in the export of beverages, spirits and vinegar, with a share of $19 \%$ in $2009 / 2010$ and $15 \%$ of the total exports in 2014/2015. Additionally, the sales of meat and edible offal rose significantly in 2014/2015. These products' share in agri-food export was nearly $36 \%$ in $2014 / 2015$ and rose to $44 \%$ in 2018/2019.

Beverages, spirits and vinegar accounted for the largest share of France's export to China. For all examined periods they accounted for, respectively, $25 \%, 61 \%, 42 \%$ and $45 \%$. In the last analyzed period it was more than 2

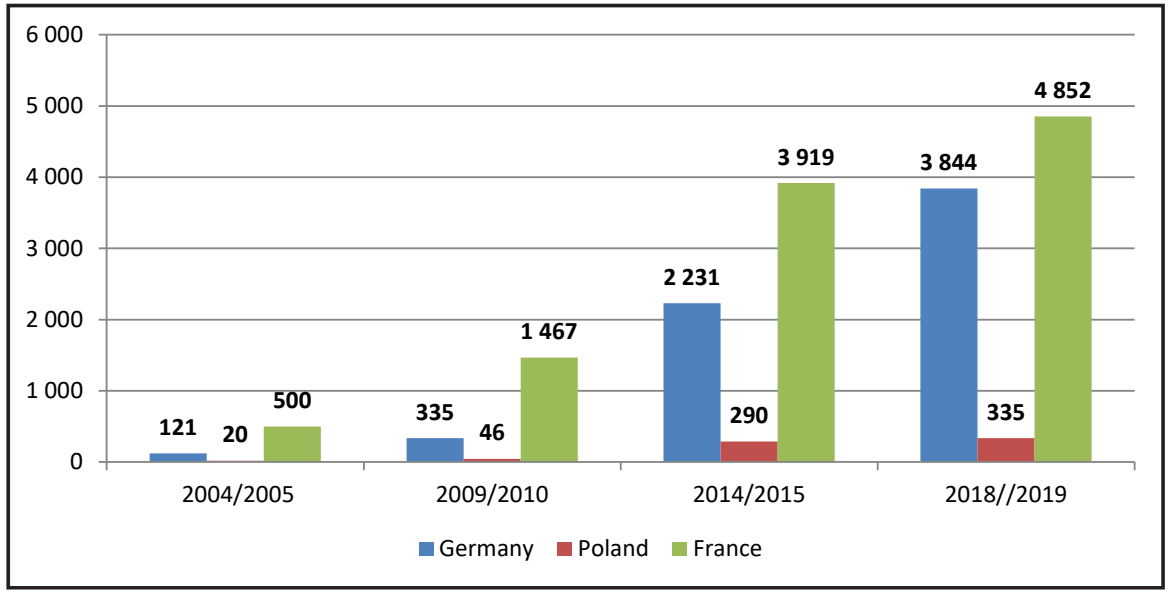

Source: Own elaboration on ComExt data

Figure 3: Agri-food exports to China (in million euros). 
billion euros. Increased exports of cereals (HS-10) were also recorded in 2004/2005 and 2014/2015. Their share in the total agri-food export was nearly $23 \%$ in $2004 / 2005$ and $25 \%$ in $2014 / 2015$. The last examined period, 2018/2019, saw the rise in the export of meat and edible offal and dairy products. For meat and edible offal that meant a rise to $11 \%$ in the total export and to $12 \%$ for dairy products.

\section{Results and discussion}

\section{Similarity of export in the EU-28 market}

In each instance, when analyzing the similarity of export between the examined countries, the threshold value determined on the basis of similarity between all EU-28 is of importance. It indicates whether the countries can be considered similar in terms of export structure in a specific market. Crossing the threshold value by several countries means that they share such a similarity. In the EU-28 market the threshold value of ESI was 0.341 . This means among Poland, Germany and France there is a similarity in the structure of export, with the exception of France and Poland in 2004/2005, when ESI fluctuated within the range of the threshold value (Table 1). The highest similarity of the export structure of agri-food products can be seen between Germany and Poland, where meat and edible offal, dairy products and preparations of cereals, flour, starch or milk enjoyed a high share throughout the entire examined period. The exports of fresh or chilled bovine meat (HS-02013000) and meat of domestic swine (HS-02031110) were particularly similar in the meat and edible offal group. In the case of dairy products, the highest similarity in the share of exported products was observed for milk and cream (HS-04012091) and for natural butter (HS-04051019). The analysis of the export of the preparations of cereals, flour, starch or milk group shows the highest similarity between food preparations for infant use (HS-19011000) and for sweet biscuits (HS-19053119). It can be seen that the similarity of the agri-food export structure between Poland and Germany was rising considerably until 2009/2010, to remain at a similar level afterwards.

The situation looked differently when viewing the overlapping of export streams, or PSI in other words. Improving results for Poland and Germany were being observed period by period, which was caused by the growth of value of the Polish agri-food exports, at a much quicker pace than in Germany. This is indicated by the increasing competition between the two countries. This happened, in particular for product groups such as meat and edible offal and tobacco and manufactured tobacco substitutes. A significant increase in the value of exported products, and thus a much higher similarity to Germany, was observed for frozen bovine meat (HS-02023090) and cigarettes (HS-24022090). For these products, the value of export from Poland was growing much faster than the value of German export, resulting in equalization of the trade volume, and even larger export from Poland than from Germany in the last examined period. The generally lower values of PSI in comparison to ESI indicate that the potential of real competition is limited by absolute values (Antimiani et al., 2012). Still, the values of both indicators are approaching each other, pointing to a similarity both with regard to the structure and to the overlapping of the streams of value of export between Germany and Poland.

The examined period also saw a marked increase of QSI values, which indicated a growing competition with regard to the quality of goods offered in the EU-28 market, between Poland and Germany. Indeed, the QSI indicator constituted around $50-55 \%$ of the PSI value throughout all examined periods. It may be therefore concluded that over half of the agri-food products exported from Poland and Germany, whose streams overlapped, is similar in terms of quality. The highest similarity was shown in groups such as meat and edible offal and dairy products. Definitive similarity in terms of quality was observed, among else, in meat of domestic swine (HS-02032955),

\begin{tabular}{|c|c|c|c|c|c|c|c|c|c|c|c|c|}
\hline & \multicolumn{4}{|c|}{ ESI } & \multicolumn{4}{|c|}{ PSI } & \multicolumn{4}{|c|}{ QSI } \\
\hline DE-PL & 0.431 & 0.518 & 0.510 & 0.507 & 0.211 & 0.306 & 0.381 & 0.422 & 0.119 & 0.149 & 0.206 & 0.216 \\
\hline DE-FR & 0.445 & 0.471 & 0.482 & 0.470 & 0.444 & 0.457 & 0.453 & 0.448 & 0.266 & 0.228 & 0.252 & 0.254 \\
\hline PL-FR & 0.338 & 0.360 & 0.369 & 0.362 & 0.186 & 0.277 & 0.338 & 0.346 & 0.067 & 0.106 & 0.135 & 0.173 \\
\hline
\end{tabular}

Source: Authors' calculation based on the 8-digit ComExt trade data

Table 1: Export similarity indicators for Poland, Germany and France on the EU-28 market. 
but also in turkeys (HS-02072620). The dairy products group showed the highest similarity for milk and cream (HS-04010000 and HS-04015039). On the other hand, the largest quality differences among exported products were shown in vegetable saps and extracts (HS-13) and in vegetable planting materials (HS-14) groups. The discussed similarity indicators of the export of agri-food products for Poland and Germany show a significant increase of competitiveness in the EU-28 market between these countries in the examined period. The underlying reason was that Poland was increasing both the value and the quality of the goods exported to the common market, becoming more competitive in the process.

Similar dynamics as for Germany and Poland was exhibited by ESI in the case of Poland and France. At first, ESI's values rapidly rose in the examined period and later remained at an approximate level. Still, the structure of the agri-food exports to EU-28 between Poland and France was visibly less similar to the structure between Germany and Poland, but, starting from 2009/2010, it exceeded the threshold value, indicating a similarity in the examined period. This was mainly caused by similar shares in the structure of export of such product groups as dairy products and preparations of cereals, flour, starch or milk. Similarity increased in particular for milk and cream (HS-04012091) and natural butter (HS-04051011), but also for food preparations for infant use (HS-19011000). In other words, the same products as for Poland and Germany.

Similarly to Poland and Germany, the PSI values for Poland's and France's agri-food exports also increased. These values were rising during the entire examined period and visibly approached the ESI values. In particular, the growing competition in the export of similar goods was caused by the overlapping of values of streams with regard to cocoa and cocoa preparations. The examined periods showed approaching export values for chocolate (HS-18069019) and spreads containing cocoa (HS-18069060). The QSI values between Poland and France also rose significantly. Whereas this indicator was 0.067 in 2004/2005, constituting around $1 / 3$ of the PSI value, it reached nearly half of the PSI value in 2018/2019. The increased similarity of the export in terms of quality was the effect of the significant increase of similarity across most groups of agri-food goods, particularly such as meat and edible offal and dairy products. Marked similarity in terms of quality was visible for products such as meat of swine
(HS-02031110) and (HS-02031219), for milk and cream (HS-04012099) and for fresh cheese (HS-04061050). The largest quality differences could be observed for products of animal origin (HS-5), vegetable saps and extracts and for vegetable planting materials.

Speaking of the similarity of the export of agri-food products in the EU-28 market between Germany and France, the analyzed indicators did not change visibly in the examined periods. Starting from 2009/2010, ESI was even lower than in the case of Germany and Poland, but the values of PSI and QSI were significantly higher for Germany and France. The PSI values were also close to the ESI values, which indicates similarity both in the structure of export and its value. The main products responsible for such a large similarity were fish and crustaceans, beverages, spirits and vinegar, and in particular products such as shrimps (HS-03061792) and water (HS-22021000). The QSI indicator amounted to over $55 \%$ of the PSI indicator in the examined years, with the only exception being 2009/2010, when QSI achieved a lower value. This situation should be associated with the turmoil affecting international trade in the wake of the global financial crisis. Although the agricultural sector has always been considered immune to various economic difficulties, the financial crisis of 2008 affected it nonetheless. Growth slowdown was observed, along with a reduction in trade flows, caused by imbalance of demand and supply (Crescimanno et al., 2014). The detailed analysis of data shows that the similarity in the quality of France's and Germany's export was high for meat and edible offal, dairy products and for beverages, spirits and vinegar. In particular, similarity was observed for products such as meat of bovine animals (HS-02012050 and HS-02012090) and for water (HS-22021000).

The analysis of the similarity of the agri-food exports to EU-28 shows that all analyzed countries can be considered competitors. The competition is particularly high between Germany and France and between Germany and Poland and slightly less intensive between Poland and France. During the examined period, Poland noticeably increased its competition towards the analyzed partners by increasing the value of export to the common market and by means of increased quality of the exported agri-food products. The analysis showed that the values of PSI and QSI indicators with Poland's partners are approaching the ones observed among long-term competitors 
in the EU-28 market - Germany and France. The 15 years that passed since its accession to the EU was used well by Poland, with regard to the growth of the agri-food export, allowing the country to reach a level at which it can compete in the common market against the region's largest agricultural producers. The obtained results are consistent with the studies on the increase of Poland's competitiveness in the common market, following the country's accession to the European Union (Antimiani et al., 2012) and with the studies showing the rise of comparative advantages in Poland's agri-food trade in the more recent period (Bojnec and Fertö, 2015). Moreover, the studies indicate that this direction has been maintained and that an increasing quality similarity is being observed among Poland, Germany and France.

\section{Similarity of export in the US market}

When analyzing the exports from Poland, Germany and France to the American market, the threshold value allowing to identify an existing similarity of the export structure was 0.118 . Assuming that all values equal to and higher than the threshold value indicate a similarity between the countries, it may be concluded that in the case of Poland, Germany and France there was a similarity of the export structure determined with the ESI indicator (Table 2). The only period when there was no similarity between Poland and France was $2018 / 2019$. The values of these indicators are very low despite the fact that the structure of export to the US is very similar in the examined countries when comparing to other EU states. This indicates that there is no intensive competition in the trade of agri-food products among EU countries on the US market. Among the examined countries, the highest similarity of structure of the exported agri-food products applied to Germany and Poland. From 2009/2010 on, the values of the indicator were constantly growing. The rise of the similarity of the export structure was affected the most by the following groups: cocoa and cocoa preparations and beverages, spirits and vinegar, in which Poland's and Germany's shares in the total agri-food exports were approaching. Within the examined groups, the highest similarity of structure was observed, among else, for chocolates (HS-18063210 and HS-18069039) and also for beer (HS-22030009).

Lower values can be observed for the PSI indicator, although the growing trend persists, just like for ESI. The markedly lower PSI values indicate a lower similarity with regard to the value of the exported agri-food products. The indicator's value was affected by the overlapping streams of the exported product groups, such as edible vegetables and certain roots and tubers and preparations of vegetables, fruit, nuts or other parts of plants, of which the highest similarities occurred for dried vegetables (HS-07129090) and for jams, among else HS-20079933.

Among the analyzed indicators for Germany and Poland, the lowest value was reached by QSI. The values were fluctuating during the first examined periods, reaching around 35-43\% for PSI, indicating that the exported products did not have a high level of similarity. QSI only reached around $50 \%$ of the PSI indicator in the last period, which was a sign of the growing similarity of the quality of agri-food products exported to the US market, further pointing to the intensifying competition between Germany and Poland. The rise of similarity was affected by groups of products like dairy products and preparations of vegetables, fruit, nuts or other parts of plants. A noticeable similarity was particularly visible for cheese (HS-04061050) and sauerkraut (HS-20059960). It must be noted that QSI values are low, but their growth during the examined period shows that Poland and Germany may be considered to be competitors in the discussed area in the US market.

A lower similarity in terms of the exported agri-food products may be noticed for Germany and France. Initially, the ESI values were on the rise, but they started to decline since 2014/2015. A decrease in the similarity in terms of the structure of export of product groups such

\begin{tabular}{|c|c|c|c|c|c|c|c|c|c|c|c|c|}
\hline & \multicolumn{4}{|c|}{ ESI } & \multicolumn{4}{|c|}{ PSI } & \multicolumn{4}{|c|}{ QSI } \\
\hline DE-PL & 0.182 & 0.166 & 0.203 & 0.227 & 0.106 & 0.110 & 0.118 & 0.145 & 0.037 & 0.047 & 0.046 & 0.073 \\
\hline DE-FR & 0.165 & 0.178 & 0.155 & 0.152 & 0.176 & 0.192 & 0.152 & 0.134 & 0.040 & 0.048 & 0.042 & 0.022 \\
\hline PL-FR & 0.142 & 0.165 & 0.125 & 0.109 & 0.065 & 0.075 & 0.056 & 0.051 & 0.015 & 0.010 & 0.008 & 0.011 \\
\hline
\end{tabular}

Source: Authors' calculation based on the 8-digit ComExt trade data

Table 2: Export similarity indicators for Poland, Germany and France on the US market. 
as products of the milling industry and beverages, spirits and vinegar contributed to the reduction of the indicator's value. Despite the drop in ESI, during all examined periods there was a similarity, between Germany and France, in the structure of the exported products, when compared to all EU states. One of the contributing factors were the similar shares in dairy products, of which natural butter (HS-04051011) exhibited the highest similarity. Despite the reduced share of the group beverages, spirits and vinegar in the export, the category of white wines (HS-22042138) exhibited a high similarity in the structure of agrifood exports.

Markedly higher values were observed for PSI, which means that export shares and value streams of the exported goods were overlapping to a large extent, simply meaning that they were similar. Just like in the case of ESI, these values were decreasing starting with the 2014/2015 period. In particular, the PSI value was affected by the similar values of the exported edible vegetables and certain roots and tubers. Large streams of mutually overlapping export values may also be observed for vegetables, e.g. HS-07108095. The PSI values exceeding ESI in 2004/2005 and in 2009/2010 are mainly the result of the fact that nearly $80 \%$ of France's agrifood exports are beverages, spirits and vinegar, whereas the remaining products have a low share in the export. Consequently, higher similarity was more often seen in the values of export of individual groups, rather than in their shares.

The reduction in the PSI value also affected the value of QSI. Not only very low QSI values can be observed, but they also have been dropping since 2009/2010. This means that, fundamentally speaking, there are no quality similarities among the exported agri-food products. Despite the fact that the values of the exported products, both from Germany and France, were growing during all examined periods, they were overlapping less and less. The quality similarity was also unaffected by the increased export values. The groups showing similarities were changing during the examined periods, so it is difficult to find one that would be similar in this regard, which confirms the lack of similarity in the quality of agri-food exports between France and Germany.

The lowest similarity of the export structure was observed for Poland and France. The similarity was further diminishing to reach 0.109 in the last examined period. This means that in the last examined period, the structure of the exported agri-food products was not similar even when compared to results from all EU states. The lowering similarity of the shares of dairy products and beverages, spirits and vinegar impacted the changes in the structure of agri-food exports and of the ESI indicator. Major changes were observed in products such as cheese, e.g., Emmental cheese (HS-04069013), and in mineral water (HS-22011019).

For PSI, the values did not cross 0.08 in the entire period. Moreover, starting from the 2009/2010 period, PSI was decreasing. A similarity in the export value was only observed for edible vegetables and certain roots and tubers, and beans (HS-07102200) in particular. As far as QSI goes, it also exhibits low values that indicate lack of competition between Poland and France in terms of the quality of exports to the US market. Further, the share of QSI in PSI values was between 13\% and $23 \%$, but the overall values of the indicators were so low that it must be concluded that there is no competition with regard to the export of agri-food products between France and Poland.

The analysis of the exports from Poland, Germany and France to the American market shows that only Germany and Poland may be considered to be competitors, even though at low intensity. The rising similarity indicators point to the growing competition within the field of exported products and their approximation in terms of quality. During the examined period, Poland and Germany noticeably increased the volume of agri-food exports to the US, affecting, in this way, the rising values of the analyzed indicators. When analyzing the selected periods in terms of price changes, one can identify approximating unit values of products, whereas these values were markedly higher in Germany than in Poland in the initial periods. It should be noted that the significantly lower values of similarity indicators for the exports to the US market, in comparison to EU-28, are caused by more restrictive trade conditions, especially in the food sector. These conditions make it difficult for the analyzed countries to intensify export in this field. Similar conclusion comes from Maltseva and Chupina (2019) analysis of EU-US barriers in agri-food trade. According to their study, tariff barriers on agricultural transatlantic trade are relatively low at first sight. However, they hide significant tariff peaks in sensitive products - especially in dairy and meat sector. On one hand, obtained results are consistent with Antimiani et al. (2012) in case of Germany, which showed that 
Poland raised its agri-food products competition with Germany in terms of PSI after the EU accession on extra-EU markets. On the other hand, Antimiani et al. (2012) found that competition with France was rising, which is in opposition to the obtained results in sense that this direction changed on US market following first few years after Poland's EU accession.

\section{Similarity of export in the Chinese market}

According to the conducted calculations, the similarity of the structure of export to the Chinese market is bigger than in the case of American market, as shown by the higher ESI values. This is also manifested by the calculated threshold similarity value for all EU states, which is 0.186 for China - almost 0.07 more than forUSA. This is despite the fact, that in terms of value, the export to China is much lower than to the US, both in the case of the analyzed countries and for the European Union in general. Consequently, a lower number of various goods are exported to China, as evidenced by the detailed ComExt data at the 8-digit level.

Relatively high ESI values were observed between Poland and Germany, with the exception of a lower value in 2009/2010 (Table 3). Until 2010, both Poland and Germany recorded low values of exports to the Chinese market and major fluctuations in the types of supplied products. Only two groups of products affected the structural similarity in this period with no changes: whey (HS-04041002) and potato starch (HS-11081300). A high similarity in the export structure was observed in 2014-2019 for milk and cream and for food preparations for infant use. PSI not only had markedly lower values, but also failed to show any rising tendencies. This was caused by the more dynamic rise of the value of export from Germany than from Poland, especially starting from 2014/2015. QSI also assumed very low values, due to a similar value achieved only for milk and cream and for food preparations for infant use. Taking into consideration all three indicators, it must be concluded that Poland and Germany are not competitors in the Chinese market with regard to agri-food exports. This is, in particular, caused by the generally low value of export from Poland in comparison to Germany.

When compared against France, Poland achieves even lower export similarity indicators than in the case of Germany. Here, ESI does not exceed the calculated threshold value of similarity, except for the last period, and even then this indicator's value is still low. Export similarities are also not shown in PSI values, not to mention the very low QSI values. For all three analyzed markets, the highest similarity in terms of agri-food exports was observed for Poland and Germany. Speaking of Poland and France, there does not seem to be a single product on the Chinese market for which the two countries can be considered competitors. It should be noted that the export from France to China exceeded even Germany's exports, which creates even wider gaps between the export from Poland and from France. It is impossible to predict any improvements, because the indicators are ambiguous and their values are low. To effectively compete in China against the largest agri-food producers from the EU, Poland would probably have to increase the value of exports.

However, the rising competition in the Chinese market is noticeable between Germany and France, as evidenced by the growth of the analyzed similarity indicators. It is hard to show any similarities in the export in the first examined period, 2004/2005. In terms of share in structure, pork export showed a similarity, but only to a moderate extent, but it went on to grow considerably in subsequent periods. In 2014/2015 and 2018/2019, the growth of the ESI value was affected by the export of pork and of milk and cream, and also of food preparations for infant use. The competition was rising most dynamically in the latter case. Throughout the two discussed periods, PSI exceeded ESI mainly due to the dominating share of wines and cognac

\begin{tabular}{cccccccccccccc}
\hline & \multicolumn{1}{c}{ ESI } & \multicolumn{1}{c}{ PSI } & \multicolumn{3}{c}{ QSI } \\
\cline { 2 - 12 } & $\mathbf{0 4 / 0 5}$ & $\mathbf{0 9 / 1 0}$ & $\mathbf{1 4 / 1 5}$ & $\mathbf{1 8 / 1 9}$ & $\mathbf{0 4 / 0 5}$ & $\mathbf{0 9 / 1 0}$ & $\mathbf{1 4 / 1 5}$ & $\mathbf{1 8 / 1 9}$ & $\mathbf{0 4 / 0 5}$ & $\mathbf{0 9 / 1 0}$ & $\mathbf{1 4 / 1 5}$ & $\mathbf{1 8} / \mathbf{1 9}$ \\
\hline DE-PL & 0.314 & 0.182 & 0.232 & 0.285 & 0.173 & 0.103 & 0.109 & 0.106 & 0.060 & 0.029 & 0.040 & 0.030 \\
DE-FR & 0.143 & 0.190 & 0.228 & 0.310 & 0.121 & 0.136 & 0.244 & 0.324 & 0.017 & 0.080 & 0.101 & 0.136 \\
PL-FR & 0.171 & 0.083 & 0.131 & 0.186 & 0.055 & 0.042 & 0.057 & 0.060 & 0.006 & 0.003 & 0.020 & 0.017 \\
\hline
\end{tabular}

Source: Authors' calculation based on the 8-digit ComExt trade data

Table 3: Export similarity indicators for Poland, Germany and France on the Chinese market. 
in France's export, which reduces the shares of other categories and limits structural similarity. Still, pork, milk and cream, and food preparations for infant use, were also similar in terms of value stream overlapping.

QSI was also rising and amounted to nearly $60 \%$ of PSI in 2009/2010, mainly due to the quality similarity of pork and milk and cream exported from Germany and France. Products from the milk and cream group and selected pork meat products (HS-02032915) kept a similar quality in 2014/2015, but in the second case, the French pork exhibited significantly higher quality at times (among else HS-02064900 and HS-02032959). This translated into a general rise of QSI, but in relation to PSI it reached 42\%. In 2018/2019, Germany and France equalized in terms of quality in the export of pork and maintained competition in the group of milk and cream products. Speaking of food preparations for infant use, which have the biggest impact on high PSI and ESI values, the quality of export from France is much lower than that from Germany. This causes QSI to remain at a relatively low level. It is interesting that in the group of food preparations for infant use, it is Poland that shows quality similarity to Germany, but the value of export is too low to consider Poland a potent competitor in this market.

EU states have comparative advantages in agrifood trade with China, in particular with regard to basic products such as: cereals, preparations of cereals, meat, dairy products, or spirits that are not produced in China (Pawlak et al., 2016). Being high-volume producers of such products, Germany and France seem to be using these advantages and compete in the Chinese market more and more intensively. Still, Poland's competition is low, despite the country's comparative advantages in dairy products or preparations of cereals, flour, starch or milk (Wang and Pawlak, 2019). This is mainly caused by excessively low value of exports to China, in comparison to the analyzed partners, or trading in goods of varying quality. It can be seen that Poland's comparative advantages in terms of some agri-food products, which are similar to Germany and France, do not necessarily translate into real competitiveness in each market partially due to export quality differences between countries. It can be linked to trade costs between China and EU involving agri-food products. Fang and Shakur (2018) stated that these cost are falling, although remain abnormally high which is especially problematic for less developed countries in EU. Obtained results also confirms Guo et al. (2015) research which shows that despite a significant structural break during financial crisis, relationship of agri-food trade between China and Germany was developing stably. Moreover, German agri-food export to China developed to the extent that allows to compete with France whose export was previously better established on Chinese market.

\section{Conclusion}

The conducted analysis of the similarity of export of agri-food products from Poland, Germany and France showed a significant competition among the examined countries in the EU-28 market. Since its accession to the EU, Poland significantly increased its agri-food exports to the common market, joining the already competing Germany and France in the process. Apart from increased value of export, a rise in similarity was also observed in the quality of the sold goods. Poland's increased competition against Germany was also observed in the US market, where agri-food products similar in terms of value and quality were being sold with growing intensity. Dairy products and preparation of vegetables played a major role in the latter case. The situation was different for French export, which was gradually becoming less similar to the German export, especially from the quality perspective. A complete lack of similarity was observed for Poland and France in the American market. Only Germany and Poland, of the examined countries, may be considered competitors on this market. The competition between these two countries is not highly intensive, but is rising from period to period.

The analysis of agri-food exports to the Chinese market showed high similarity in terms of structure between Poland and Germany, but Poland's export value is too low to speak of any effective competition in this market. This also results in no similarity with regard to the quality of the exported products within the overlapping value streams. Nevertheless, Germany and France are competitors in the Chinese market and they significantly increased the similarity of the export of agri-food products in the examined period. This applied both to the value aspect and, though to a lesser degree, to the quality aspect. There is no similarity between Poland's and France's export to the Chinese market. In each of the examined markets, Poland's agri-food export was more similar to the export 
from Germany than to the export from France. Generally, Poland is only competing with France in the discussed scope in the EU-28 market.

The conducted analysis fills in the gap in the research on the similarity of the export of agri-food products, where the issue of quality of products is often disregarded. Very little attention is also paid to CEEC which, following their accession to the EU, could benefit from the opening of new markets - potential export directions. Three similarity indicators were used throughout the study: ESI, PSI and QSI, which allowed a comprehensive analysis of the agri-food exports. A method was also proposed to determine the similarity of the structure of export on the basis of similarity results for the entire population, due to ESI's high sensitivity to the level of data aggregation. This constitutes a certain improvement in comparison to an arbitrarily accepted value over which countries should be considered similar in terms of the structure of export. Regardless, caution is still warranted when analyzing the results and the indicator's absolute value should be taken into account. A limitation is imposed by the certain degree of sensitivity of all similarity indicators to the level of aggregation of data and caution must be exercised when interpreting the obtained results, paying attention to their changes over time and mutual relations, not just absolute values. The authors used a method of their own design to measure the similarity of quality for the purpose of quality analysis with the use of export unit values. The new method produces the same results when comparing object $\mathrm{A}$ to object $\mathrm{B}$, as when comparing object $\mathrm{B}$ to object A. This also constitutes a certain improvement in relation to the method previously used in reference literature. Future research may focus on Poland's relations with other EU agri-food exporters or on the relations of other CEEC countries, as these are issues rarely addressed in reference literature

\section{Acknowledgements}

This research was supported by the National Science Centre, Poland [grant number: 2017/27/N/ HS4/01534].

\author{
Corresponding authors \\ Mr. Bartłomiej Bajan \\ Faculty of Economics and Social Sciences, Poznan University of Life Sciences, \\ Wojska Polskiego 28, 60-637 Poznań, Poland \\ Phone: +48618466379,E-mail: bartlomiej.bajan@up.poznan.pl
}

\title{
References
}

[1] Abrham, J., Strielkowski, W., Vošta, M. and Šlajs, J. (2015) "Factors that influence the competitiveness of Czech rural SMEs", Agricultural Economics, Vol. 61, No. 10, pp. 450-460. E-ISSN 1805-9295, ISSN 0139-570X. DOI 10.17221/63/2015-AGRICECON.

[2] Antimiani, A. and Henke, R. (2007) "Old and new partners: Similarity and competition in the EU foreign agri-food trade”, Acta Agriculturae Scand Section C, Vol. 4, No. 3, pp. 129-138. ISSN 1650-7541. DOI 10.1080/16507540701596925.

[3] Antimiani, A., Carbone, A., Costantini, V. and Henke, R. (2012) "Agri-food exports in the enlarged European Union”, Agricultural Economics, Vol. 58, No. 8, pp. 354-366. ISSN 0139-570X. DOI 10.17221/145/2011-AGRICECON.

[4] Anwar, S. and Sun, S. (2018) "Foreign direct investment and export quality upgrading in China's manufacturing sector", International Review of Economics \& Finance, Vol. 54, pp. 289-298. ISSN 1059-0560. DOI 10.1016/j.iref.2017.09.009.

[5] Bang, S. and Tuo, Y. (2013) "Trade relation between China and ASEAN countries: Competition or integration? - An empirical analysis based on export similarity, trade integration and regular market share model", In: IEEE 2013 International Conference on Management Science and Engineering $20^{\text {th }}$ Annual Conference Proceedings, pp. 1134-1138. DOI 10.1109/ICMSE.2013.6586417.

[6] Bilan Y., Mishchuk, H., Roshchyk, I. and Kmecova I. (2020) "Analysis of Intellectual Potential and its Impact on the Social and Economic Development of European Countries", Journal of Competitiveness, Vol. 1, pp. 22-38. ISSN 20513143. DOI 10.7441/joc.2020.01.02. 
[7] Blázquez-Fernández, C., Cantarero-Prieto, D. and Pascual-Sáez, M. (2018) "Okun’s Law in Selected European Countries (2005-2017): An Age and Gender Analysis", Economics and Sociology, Vol. 11, No. 2, pp. 263-274. E-ISSN 2306-3459, ISSN 2071-789X. DOI 10.14254/2071-789X.2018/11-2/18.

[8] Bojnec, Š. and Fertő, I. (2010) "Quality differentiation in East-West European agro-food trade during the pre-accession", Transformations in Business \& Economics, Vol. 9 No. 3, pp. 36-51. ISSN 1392-8732.

[9] Bojnec, Š. and Fertö, I. (2009) "Agro-food trade competitiveness of Central European and Balkan countries", Food policy, Vol. 34, No. 5, pp. 417-425. ISSN 0306-9192. DOI 10.1016/j.foodpol.2009.01.003.

[10] Bojnec, Š. and Fertő, I. (2015) "Agri-food export competitiveness in European Union countries". Journal of Common Market Studies, Vol. 53, No. 3, pp. 476-492. ISSN 1468-5965. DOI $10.1111 /$ jems.12215.

[11] Brugier, C. M. (2017) "The EU's trade strategy towards China: lessons for an effective turn", Asia Europe Journal, Vol. 15, No. 2, pp. 199-212. ISSN 1610-2932. DOI 10.1007/s10308-017-0475-4.

[12] Caporale, G. M., Rault, C., Sova, R. and Sova, A. (2012) "European free trade agreements and trade balance: Evidence from four new European Union members", The Journal of International Trade \& Economic Development, Vol. 21, No. 6, pp. 839-863. ISSN 0963-8199. DOI 10.1080/09638199.2011.555562.

[13] Chomątowski, S. and Sokołowski, A. (1978) "Taksonomia struktur", Przegląd Statystyczny, Vol. 2, pp. 217-226. (in Polish). ISSN 0033-2372.

[14] Crescimanno, M., Galati, A. and Bal, T. (2014) "The role of the economic crisis on the competitiveness of the agri-food sector in the main Mediterranean countries", Agricultural Economics, Vol. 60, No. 2, pp. 49-64. ISSN 0139-570X. DOI 10.17221/59/2013-AGRICECON.

[15] De Benedictis, L. and Tajoli, L. (2007) "Economic integration and similarity in trade structures", Empirica, Vol. 34, No. 2, pp. 117-137. ISSN 0340-8744. DOI 10.1007/s10663-006-9024-X.

[16] Fang, L. and Shakur, S. (2018) "Impact of trade cost on China-EU agri-food trade", Journal of Chinese Economic and Business Studies, Vol. 16, No. 3, pp. 259-274. ISSN 1476-5284. DOI 10.1080/14765284.2018.1482089.

[17] Finger, J. M. and Kreinin, M. E. (1979) "A Measure of 'Export Similarity' and Its Possible Uses”, The Economic Journal, Vol. 89, No. 356, pp. 905-912. ISSN 0013-0133. DOI 10.2307/2231506.

[18] Guo, Z., Feng, Y. and Gries, T. (2015) "Changes of China's agri-food exports to Germany caused by its accession to WTO and the 2008 financial crisis". China Agricultural Economic Review, Vol. 7, No. 2, pp. 262 - 279. ISSN 1756-137X. DOI 10.1108/CAER-11-2013-0152.

[19] Guo, Z., Feng, Y. and Tan, X. (2011) "Short-and long-term impact of remarkable economic events on the growth causes of China-Germany trade in agri-food products", Economic Modelling, Vol. 28, No. 6, pp. 2359-2368. ISSN 0264-9993. DOI 10.1016/j.econmod.2011.06.007.

[20] Hallak, J. C. (2006) "Product quality and the direction of trade", Journal of international Economics, Vol. 68, No. 1, pp. 238-265. ISSN 0022-1996. DOI 10.1016/j.jinteco.2005.04.001.

[21] Hummels, D. and Klenow, P. J. (2005) "The variety and quality of a nation's exports", American Economic Review, Vol. 95, No. 3, pp. 704-723. ISSN 0002-8282. DOI 10.1257/0002828054201396.

[22] Janda, K., Rausser, G. and Strielkowski, W. (2013) "Determinants of profitability of Polish rural micro-enterprises at the time of EU Accession", Eastern European Countryside, Vol. 19, No. 1, pp. 177-217. DOI 10.2478/eec-2013-0009.

[23] Janský, P. (2010) "Rising unit values of Central and Eastern European exports: Rising quality in transition?", International Journal of Economic Policy in Emerging Economies, Vol. 3, No. 2, pp. 147-157. ISSN 1752-0452. ISSN 1232-8855. DOI 10.1504/IJEPEE.2010.033777.

[24] King, A. (1993) "A note on export unit value indices in competitiveness variables", Bulletin of Economic Research, Vol. 45, No. 1, pp. 69-77. ISSN 1467-8586. DOI 10.1111/j.1467-8586.1993.tb00557.x. 
[25] Kukuła, K. (2010) "Statystyczne studium struktury agrarnej w Polsce", Warsaw, Wydawnictwo Naukowe PWN, p. 227. ISBN 978-83-01-15950-4. (in Polish).

[26] Larue, B. (2018) "Economic Integration Reconsidered", Canadian Journal of Agricultural Economics, Vol. 66, No. 1, pp. 5-25. ISSN 1744-7976. DOI 10.1111/cjag.12164.

[27] Luo, X., Han, Y. and Zhang, F. (2018) "Competition of trade and investment between Guangzhou and BRI countries: an empirical analysis based on Export Similarity Index", In: MATEC Web of Conferences, Vol. 175. EDP Sciences. ISSN 2261-236X. DOI 10.1051/matecconf/201817504032.

[28] Maciejewski, M. (2019) "The Similarity of the Demand Structure as a Determinant of the Commodity Structure of Bilateral Trade in the European Union Countries", Entrepreneurial Business and Economics Review, Vol. 7, No. 2. E-ISSN 2353-8821, ISSN 2353-883X. DOI 10.15678/EBER.2019.070214.

[29] Maciejewski, M. and Wach, K. (2019) "What determines export structure in the EU countries? The use of gravity model in international trade based on the panel data for the years 1995 2015", Journal of International Studies, Vol. 12, No. 1, pp. 151-167. ISSN 20718330. DOI 10.14254/2071-8330.2019/12-1/10

[30] Maltseva, V. and Chupina, D. (2019) "Barriers in the EU-US Agricultural Trade within TTIP Agenda", World Economy and International Relations, Vol. 63, No 2, pp. 36-45. ISSN 0131-2227. DOI 10.20542/0131-2227-2019-63-2-36-45.

[31] Marques, H. (2011) "Asymmetries in heterogeneous integrated areas: Evidence from sectoral trade between old and new EU members", The Journal of International Trade and Economic Development, Vol. 20, No. 1, pp. 5-29. ISSN 0963-8199. DOI 10.1080/09638199.2011.538181.

[32] Mau, K. (2019) "Foreign competition and quality sorting: Overlaps in US and Chinese exports". The World Economy, Vol. 42, No. 8, pp. 2300-2325. ISSN 1467-9701. DOI 10.1111/twec.12791.

[33] Meunier, S. (2005) "Trading Voices: The European Union in International Commercial Negotiations", Princeton, Princeton University Press, p. 248. ISBN 978-0691130507.

[34] Meunier, S. and Nicolaïdis, K. (2006) “The European Union as a conflicted trade power", Journal of European Public Policy, Vol. 13, pp. 906-925. ISSN 1350-1763. DOI 10.1080/13501760600838623.

[35] Nguyen, T. N. A., Pham, T. H. H. and Vallée, T. (2017) "Similarity in trade structure: Evidence from ASEAN+ 3", The Journal of International Trade and Economic Development, Vol. 26, No. 8, pp. 1000-1024. ISSN 0963-8199. DOI 10.1080/09638199.2017.1331372.

[36] Niemi, J. S. and Huan-Niemi, E. (2007) "EU-China agricultural trade in relation to China's WTO membership", International Food and Agribusiness Management Review, Vol. 10, pp. 41-62. ISSN 1559-2448. DOI 10.22004/ag.econ.8163.

[37] Novotná, T., Telò, M., Morin, J. F. and Ponjaert, M. F. (2015) "The politics of transatlantic trade negotiations: TTIP in a globalized world", Farnham, Ashgate Publishing, 256 p. ISBN 978-1-4724-4364-9.

[38] Pawlak, K. (2018) "Comparative advantages of the Polish agri-food sector on the US market". In Proceedings of the International Scientific Conference: Economic Sciences for Agribusiness and Rural Economy Vol. 1, No. 2, pp. 223 - 230. ISBN 978-83-7583-803-9. DOI10.22630/ ESARE.2018.2.29.

[39] Pawlak, K., Kołodziejczak, M. and Xie, Y. (2016) "Changes in foreign trade in agri-food products between the EU and China", Journal of Agribusines and Rural Development, Vol. 42, No. 4, pp. 607-618. ISSN 1899-5241. DOI 10.17306/JARD.2016.87.

[40] Pomfret, R. (1981) “The impact of EEC enlargement on non-member Mediterranean countries' exports to the EEC", The Economic Journal, Vol. 91, No. 363, pp. 726-729. ISSN 0013-0133. DOI $10.2307 / 2232837$ 
[41] Preeg, E. H. (1998) "From here to free trade: Essays in post-Uruguay round trade strategy", Chicago, University of Chicago Press, 161 p. ISBN 978-0226679624.

[42] Priede, J. and Feng, H. (2017) "Evaluation of Latvia-China Trade Potential", European Research Studies, Vol. 20, No. 3A, pp. 931-941. ISSN 1108-2976. DOI 10.35808/ersj/755.

[43] Rondinella, S., Agostino, M., Demaria, F. and Drogué, S. (2019) "Similarity and Competition in the Agri-Food Trade among European Mediterranean Countries", The International Trade Journal, Vol. 33, No. 5, pp. 444-468. ISSN 0885-3908. DOI 10.1080/08853908.2019.1587324.

[44] Silver, M. (2009) "Do unit value export, import, and terms-of-trade indices misrepresent price indices?", IMF Staff Papers, Vol. 56, No. 2, pp. 297-322. ISSN 2041-4161. DOI 10.1057/imfsp.2008.24

[45] Smutka, L., Maitah, M. and Svatoš, M. (2019) "The Czech Agrarian Trade Comparative Advantages Distribution Based on Value and Volume Approach", Acta Universitatis Agriculturae et Silviculturae Mendelianae Brunensis, Vol. 67, No. 6, pp. 1613-1625. ISSN 1211-8516. DOI 10.11118/actaun201967061613.

[46] Stiglitz, J. E. (1987) "The causes and consequences of the dependence of quality on price", Journal of Economic Literature, Vol. 25, No. 1, pp. 1-48. ISSN 0022-0515. [Online] Available: https://www.jstor.org/stable/2726189. [Accessed: 12 Feb. 2020].

[47] Svatoš, M. and Smutka, L. (2012) "Development of agricultural trade and competitiveness of the commodity structures of individual countries of the Visegrad Group", Agricultural Economics, Vol. 58, No. 5, pp. 222-238. ISSN 0139-570X. DOI 10.17221/51/2011-AGRICECON.

[48] Svatoš, M., Smutka, L., Smutka, B. A. M. and Mousbah, S. A. A. (2013) "Development of Visegrad countries' agricultural trade in relation to agricultural production development", AGRIS on-line Papers in Economics and Informatics, Vol. 5, pp. 61-71. ISSN 1804-1930. DOI 10.22004/ag.econ.148104.

[49] Taylor, R. and Jaussaud, J. (2018) "China's Global Political Economy: Managerial Perspectives", London, Routledge, 316 p. ISBN 9781138103733 . DOI 10.4324/9781315102566.

[50] Tocci, N. (2008) "Who is a normative foreign policy actor? The European Union and its global partners”, Brussels, CEPS Paperback Series, 336 p. ISBN 9789290797791.

[51] Torok, A. and Jambor, A. (2013) "Competitiveness and Geographical Indications: the case of fruit spirits in Central and Eastern European countries", Studies in Agricultural Economics, Vol. 115, pp. 25-32. ISSN 2063-0476. DOI 10.22004/ag.econ.146816.

[52] Wang, P. and Pawlak, K. (2019) "Changes in Foreign Trade in Agricultural Products between China and Poland", Agricultural and Forestry Economics and Management, Vol. 2, No. 1, 1-10. ISSN 2616-2202. [Online] Available: https://www.clausiuspress.com/article/281.html. [Accessed: 15 Feb. 2020].

[53] Yang, J., Černevičiūte, J., Strazdas, R. and Tvaronavičiené, M. (2019) "Stimulation of cultural and creative industries clusters development: A case study from China", Terra Economicus, Vol. 17, No. 3, pp. 169-184. E- ISSN 2410-4531, ISSN 2073-6606.

[54] Zheng, Y. and Qi, J. (2007) "Empirical Analysis of the Structure of Sino-US Agricultural Trade", China and World Economy, Vol. 15, No. 4, pp. 35-51. ISSN 1749-124X. DOI 10.1111/j.1749-124X.2007.00074.X. 


\section{Appendix}

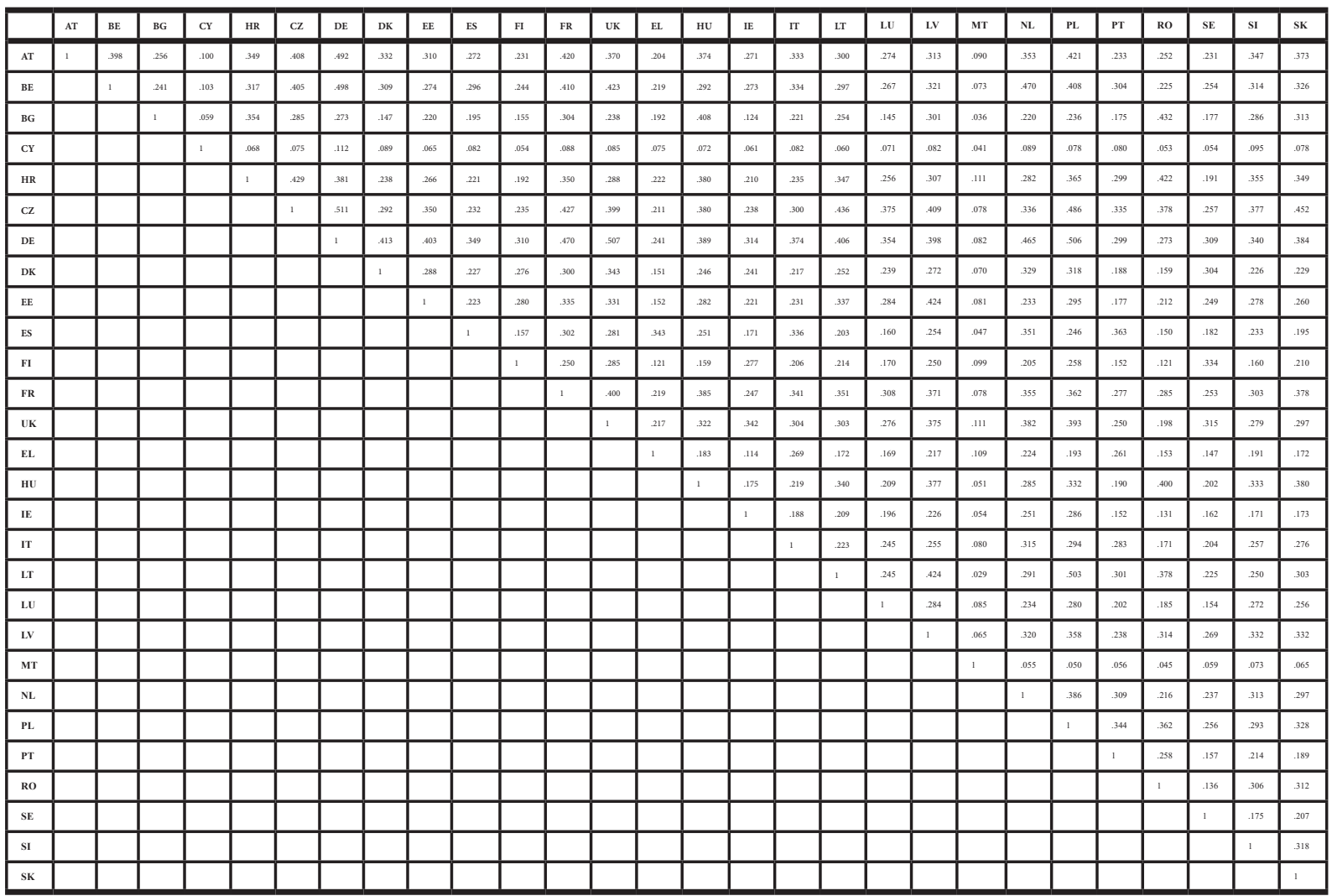

Source: Authors' calculation based on the 8-digit ComExt trade data.

Table A1: Agri-food export structure similarity matrix in 2018/2019 on the EU-28 market.

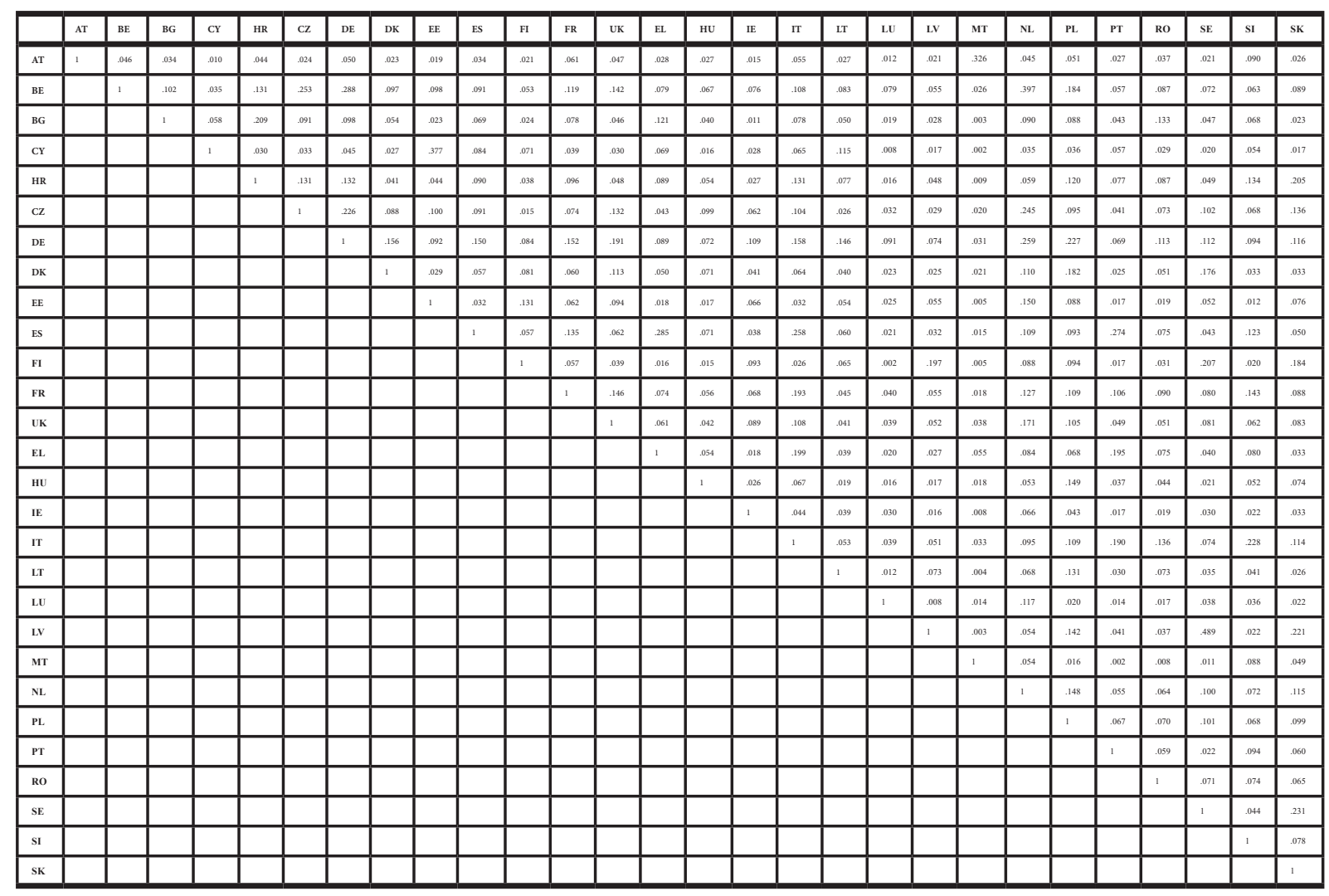

Source: Authors' calculation based on the 8-digit ComExt trade data.

Table A2: Agri-food export structure similarity matrix in 2018/2019 on the US market. 


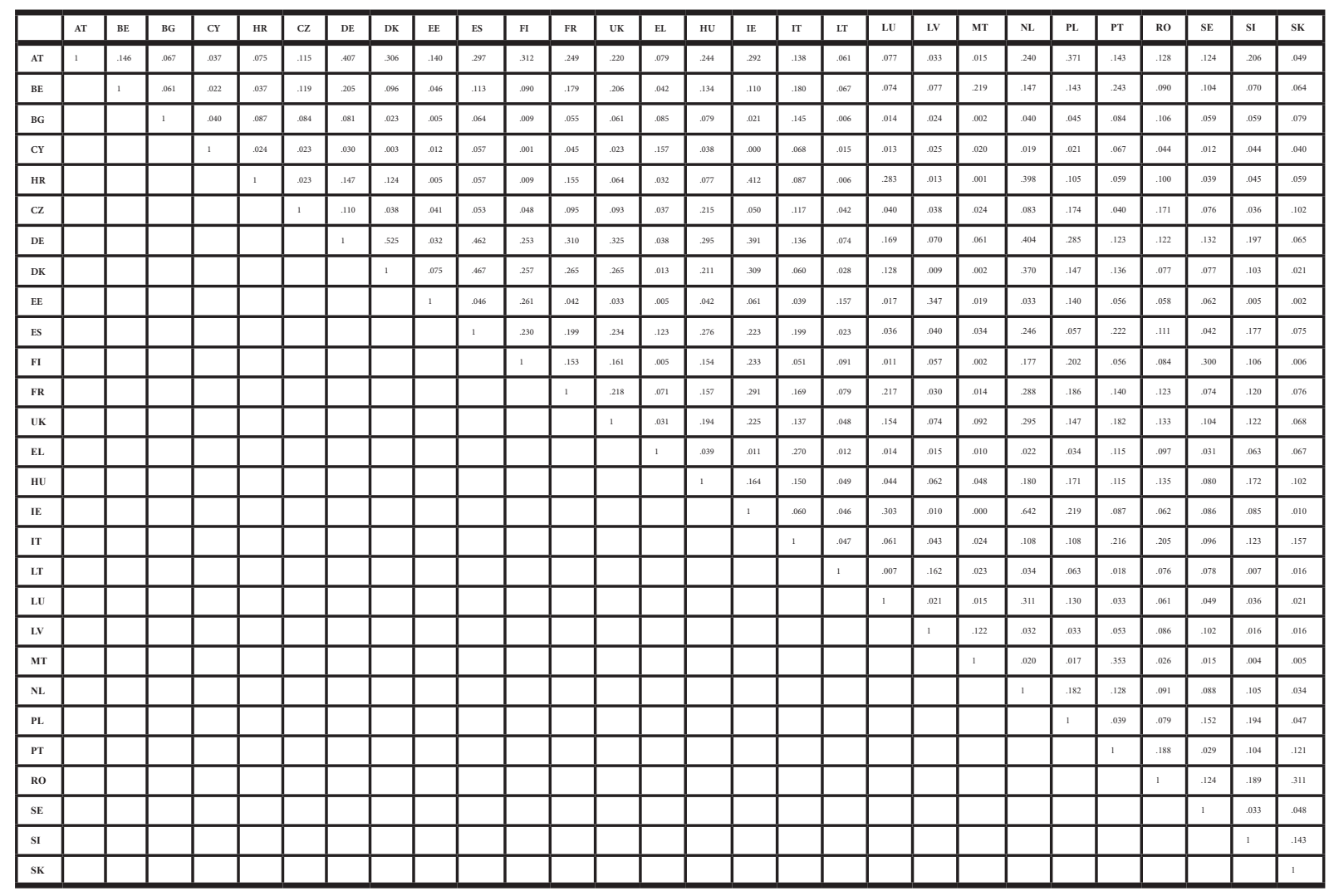

Source: Authors' calculation based on the 8-digit ComExt trade data.

Table A3: Agri-food export structure similarity matrix in 2018/2019 on the Chinese market. 